\title{
Pronominal Clitics in European and Brazilian Portuguese
}

\author{
INÊS DUARTE \\ GABRIELA MATOS \\ ANABELA GONÇALVES
}

\begin{abstract}
This paper addresses two issues, the categorial nature of (pronominal) clitics and the conditions ruling their surface distribution as proclitics and enclitics, which we take as related. We claim that pronominal clitics are defective functional heads consisting of a bundle of $\phi$-features, and hence, that they are merged in a fixed position in the functional structure of the clause. The (micro)variation in clitic order patterns will be accounted for through the interplay of verb movement and the Proclisis Parameter: when languages set the value 'yes' for this parameter, proclisis is the dominant pattern, whereas in languages setting the value 'no' for the same parameter, enclisis dominantly occurs; other differences between Romance languages and, in particular, EP and BP, are accounted for by the properties of the nodes $T$ and Asp, namely, their ability to attract $V$ and or to check uninterpretable features through Agree without Attract.
\end{abstract}

\section{Introduction}

This paper addresses two issues in the long standing debate on Romance pronominal clitics: their categorial nature and the conditions ruling their surface distribution as proclitics and enclitics ${ }^{1}$.

In dealing with these two issues, we adopt a comparative approach along the lines first sketched in Chomsky (1981) and further developed within the Minimalist framework.

\footnotetext{
${ }^{1}$ Mesoclisis will not be addressed in this paper, since it is a regressing pattern in the grammar of EP and is virtually non existent in the innovative grammar of BP.
} 
Although our main concern is the microvariation between EP and BP, we will propose a parametric account intended to capture universal and particular properties of pronominal clitics across languages.

Section 2 discusses different proposals about the categorial status of pronominal clitics, arguing that they should be better understood as defective functional heads, consisting of a bundle of $\phi$-features.

Section 3 addresses the problem of clitic order patterns. Building on the conclusions of section 2, we suggest clitics are merged in a fixed position in the clause structure, above the Asp node. We further claim that the variation between enclisis and proclisis crosslinguistically derives from the setting of the Proclisis Parameter. When languages set the value 'yes' for this parameter, proclisis is the dominant pattern, whereas in languages setting the value 'no' for the same parameter, enclisis dominantly occurs. We will argue that the innovative grammar of BP sets the value 'yes' for the Proclisis Parameter, together with Spanish, (standard) Italian and French, whilst EP, together with, possibly among others, Berber and Cypriot Greek, sets the value 'no' for the same parameter.

Other differences between Romance languages and, in particular, EP and $\mathrm{BP}$, are accounted for by the properties of the nodes $\mathrm{T}$ and Asp, namely, their ability to attract $\mathrm{V}$ and or to check uninterpretable features through Agree without Attract.

\section{On the categorial nature of pronominal clitics}

Different approaches to the categorial status of pronominal clitics in Romance have been proposed in the literature; while some analyses consider pronominal clitics do not syntactically differ from regular determiners and claim that cliticization is just a phonological process (e.g., Uriagereka 1996, Raposo and Uriagereka 2005), others argue that pronominal clitics also present morpho-syntactic specific properties, related to their morphological nature, as a functional affix-like category (e.g. Sportiche 1998), or to their defective syntactic structure which categorially distinguishes them from the full categories they stand for (e.g., Déchaine and Wiltschko 2002).

\subsection{Pronominal clitics as DPs}

Developing a proposal by Postal (1966), some analyses claim that pronominal clitics in Romance are cases of Ds instantiated by the definite article that heads full DPs (e.g., Uriagereka 1996). The clitic behaviour of these pronouns is seen as a consequence of the phonological dependence of a specific determiner head (in particular, the definite article) on their hosts in these languages: when there is no overt NP material inside the DP for the article to cliticize on, (1), it must move to find an adequate phonological host; otherwise it remains (or may remain) inside the DP, (2): 
(1) a. Ele cumprimentou-os.

he greeted-CL-acc-3pl-masc

'He greeted them'

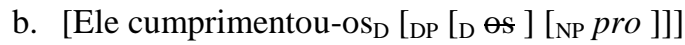

(2) a. Ele cumprimentou os professores.

$(\mathrm{EP}=\mathrm{BP})$

'He greeted the teachers'

b. [Ele cumprimentou [DP [D os ] [NP professores ]]]

However, although 3rd person Romance clitics and definite articles are diachronically related, since they both originate from Latin demonstrative pronouns, this is not the case for 1 st and 2 nd person forms, which derive from the correspondent Latin personal pronouns (Ernout and Thomas 1951: §207, Vincent 1988: 42, a.o.).

Besides, clitic pronouns in Romance, named special clitics in Zwicky (1977), present specific syntactic and phonological properties that distinguish them from articles and other simple phonological clitics (Zwicky 1977, Otero 1996, Vigário 1999, 2001, a.o.). In particular, clitic pronouns require an active functional host (Kayne 1991) with relevant formal features that must be headed by an overt verbal element, as illustrated for European Portuguese (EP) in (3) and (4).

(3) Eles estão-me a dar muita força _. . (EP) they are-CL-dat-1sg to give much strengh _

'They are truly supporting me.'

(4) a. Ele é-lhes fiel.

$\mathrm{He}$ is-CL-dat-3pl faithful

'He is faithful to them.'

b. *Ele é fiel-lhes.

he is faithful-CL-dat-3pl

c. Ele é fiel aos seus amigos.

'He is faithful to his friends.'

In (3), the clitic me ('me') is interpreted as the indirect object of dar ('to give') but its host is the fully inflected auxiliary verb estão ('are'); similarly in (4) the clitic is associated with the complement of the adjective fiel ('faithful'), but it cliticizes onto the functional head instantiated by the copular verb é ('is').

In contrast, the definite article in current EP cannot cliticize onto a verbal element (5), and apparently has not a fixed functional host inside the NP domain, (6): 
(5) a. Ele está a apoiar o irmão. he is to support the brother

'He is supporting his brother.'
b. *Ele está-o he

$$
\text { a apoiar _ irmão }
$$$$
\text { he is-the-DefArt to support __ brother. }
$$

(6) a. o [NP dicionário $]$
b. o [NP [ mais] importante dicionário de Inglês] 'the most important dictionary of English'
c. o [NP _ de Inglês $]$
the _ of English
'the one of English'

The behavior of definite articles illustrated in (5)-(6) and of other functional words subject to phonological operations of cliticization is similar: strict adjacency is required and no specialized functional host is needed, as shown with the complementizer que ('that'), in (7).

(7) a. os livros [CP $O p_{w^{-}}$que [IP eu comprei $\left.t_{\mathrm{wh}^{-}}\right]$]

[kj'ew]

'the books that I bought'

b. os livros [CP $O p_{\text {wh- }}$ que [IP andei a ler $t_{\mathrm{wh}^{-}}$]

[Kjẽ 'dej]

the books that walked-1sg to to-read

'the books I have been reading'

Summarizing, the data above show that, in EP, the clitic property of complement pronouns cannot be reduced to a phonological process and that some morphological or syntactic features are at stake.

\subsection{Pronominal clitics vs. affixes}

The closeness of pronominal clitics and affixes, namely inflectional ones, has often been noticed. Adopting this view, Sportiche (1998) assumes that each pronominal clitic heads a functional projection with voice features: passive, accusative, dative, etc. Considering French, he proposes these voice projections dominate the core inflectional projections of sentence structure, in particular TP, as in (8):

(8) $[$ NomV $[$ AccV $[$ DatV ...[T .... [ V ... XP*/YP*/ZP*]]]]]

Sportiche suggests that clitics may be conceived either as agreement features heading their own clitic projections, or as morphemes generated in their verbal host, in accordance with Chomsky (1993)'s proposal that words 
are inserted fully inflected in Syntax. In both cases, clitics do not move, the movement effects in clitic constructions being a consequence of raising of the nominal category associated with the clitic to the specifier position of the clitic projection in order to enter into a Spec-Head agreement relation with the clitic, $(9)^{2}$.

$$
\text { (9) }[\ldots[[\mathrm{DP} * \text { pro }][\mathrm{AccV} \text { CL }][\ldots \mathrm{DP} *]]]
$$

Although accepting that some specific functional projection is involved in the derivation of clitic constructions, as we will argue below, we reject the view that pronominal clitics are affixes, either conceived as morphemes that build up a word with their verbal host in the Lexicon, or as affixes that spell-out specific inflectional heads. In fact, both syntactic and phonological arguments support the distinction between pronominal clitics and affixes. Syntactically, Romance clitics differ from affixes, namely because they do not occupy a rigid position with respect to the verb, occurring as proclitics or enclitics to their host, (10), (11): ${ }^{3}$

$$
\begin{aligned}
& \text { (10) a. Io me lo ricordo. } \\
& \text { I CL-acc-1sg CL-acc-3sg-masc remember } \\
& \text { 'I remember it.' } \\
& \text { b. Studiandolo, potrei ritenerlo meglio. } \\
& \text { StudyingCL-acc-3sg-masc, can-1sg remember it.CL better } \\
& \text { 'I can remember it better, by studying it.' } \\
& \text { (11) a. Te daré algunos libros. } \\
& \text { CL-dat-2sg will-1sg-give some books } \\
& \text { 'I will give you some books.' } \\
& \begin{array}{lll}
\text { b. Guardé el libro sin haberlo } & \text { leído. } \\
\text { kept-1sg the book without havingCL-acc-3sg-masc } & \text { read } \\
\text { 'I kept the book without having read it.' } &
\end{array}
\end{aligned}
$$

Besides, these order patterns are triggered by elements that are inoperative in determining the prefix or suffix nature of inflectional (or derivational) affixes in the same languages. Thus, in Italian and Spanish, proclisis occurs in the presence of finite tense features, (10a), (11a), and enclisis in non-finite clauses, (10b), (11b); in EP, the sentential negation marker triggers proclisis in finite and non-finite sentences, (12b). However, none of these elements

\footnotetext{
2 According to Sportiche (1998), this movement would be required to satisfy the Clitic Criterium.

${ }^{3}$ Proposals that assume that clitics are not associated to an argument position and that they may be analysed as a constituent of a lexical compound formed in the Lexicon (Galves and Abaurre 1996) also face the problem of accounting for the mobility of clitics around their host.
} 
affect the affix status of verbal inflection affixes, converting them from a suffix into a prefix — see the contrast between (12b) and (12c).

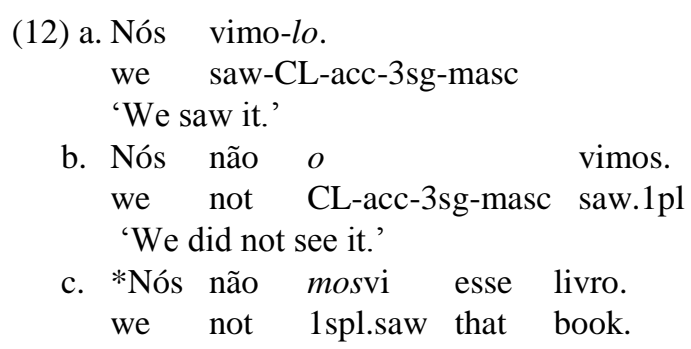

From a phonological point of view, pronominal clitics also differ from affixes, since they do not affect the phonological information of the word built in the Lexicon (Vigário 1999, 2001). In particular, in contrast with suffixes, clitics do not change the position of word stress, (13):

$$
\begin{array}{llll}
\text { di [zí] amos } & \text { di [zí] amo - lo } & \text { di [zí] amo-no - lo } \\
\text { tell-PAST 1pl } & \text { tell - IMP 1pl it.CL tell-PAST 1pl -us.CL - it.CL }
\end{array}
$$

The data presented in (13) also argue against non-unified approaches to pronominal clitic placement that assume proclitic pronouns are syntactic units (words or phrases), whereas enclitic ones are affixes (e.g., Galves 2000).

\subsection{Pronominal clitics as $\phi$-words}

Adopting the DP structure in (14), Déchaine and Wiltschko (2002) argue that pronouns belong to one of the following categories: pro-DPs, pro- $\phi$ Ps and pro-NPs, each pronoun of a higher category including the lower subtype(s). French 1 st and 2 nd person clitics as well as the definite 3rd person L-clitics are characterised as pro- $\phi$ Ps pronouns ${ }^{4}$.

$$
[\mathrm{DP} D[\phi P \phi[N P \mathrm{~N}]]]
$$

Extending this proposal to the core clitic pronouns in Romance languages, we assume that these elements, whether enclitic or proclitic, are lexical units of word level, consisting of a bundle of $\phi$-features ${ }^{5}$ (person, number and gender), which, due to their (phonologic and syntactic) deficient status, require a specific host. Additionally, we assume that clitics are merged in the syntactic derivation in a fixed position of the clause architecture, as suggested in Sportiche (1988) and Schlonsky (2004).

\footnotetext{
${ }^{4}$ Considering its distribution, Déchaine and Wiltschko (2002) claim that the clitic en in French is a pro-N.

${ }^{5}$ Galves (2000) made a similar claim, but restricted to proclitic pronouns in Portuguese.
} 
These proposals, taken together with the hypothesis that clitics may be associated with the predicate frame of the main verb (Jaeggli 1982, Belletti 1982, Duarte 1983, a.o.), refined as in Sportiche (1998), can account for the diversity of Romance clitics, illustrated below for Portuguese: definite non-reflexive clitics (15), reflexive clitics/reciprocal (16), arbitrary nominative clitics (17), predicative clitics (18), passive clitics (19), ergative clitics (20), and inherent clitics (21).

(15) Non-reflexive clitic

Ser índio não lhe dá o direito de cometê-lo. (EP=BP) to be Indian not him.CL give the right to commit-it.CL.

'To be an Indian does not allow him to commit it.'

(In Época, 116/2000)

(16) Reflexive/reciprocal clitic

Cenas de violência ocorrem, sem que as autoridades ( $\mathrm{EP}=\mathrm{BP})$ scenes of violence occur, without that the authorities se mobilizem

themselves.CL mobilize

'Scenes of violence occur, without the mobilization of the authorities.'

(In Época 109/2000)

(17) Nominative clitic

Trabalha-se demasiado.

work-oneself.CL too much

'One works too much.'

(18) Predicative clitic

Eles já estãopreocupados, e nós também $o$ estaremos they already are worried, and we also so.CL will be em breve.

(EP)

soon

'They are already worried, and so we will be soon.'

(19) Passive clitic

Penduraram-se os quadros na parede.

hung-Cl-3pl-Passive. The paintings on the wall.

'The paintings were hung on the wall.'

(20) Ergative clitic

$\mathrm{O}$ gelo derreteu-se e nós assustámo-nos (EP)

The ice melted-itself. $\mathrm{Cl}$ and we got scared ourselves.CL

com o degelo repentino.

with the thaw sudden

'The ice melted and we got scared with the sudden thaw.' 


\section{(21) Inherent clitic}

$\mathrm{Tu}$ zangaste-te.

You angered-yourself.CL

'You got angry.'

As far as their content is concerned, the above mentioned clitics may be classified into three main subtypes: (i) substantive clitics, ranging over clitics with argumental content (definite reflexive/reciprocal, non-reflexive and arbitrary nominative clitics) or predicative content (predicative clitic); (ii) clitics changing the argument frame of the main verb (passive and ergative clitics); (iii) clitics devoid of any substantive or functional content (inherent clitic).

Considering these cases, we propose the structures in (22)-(25), below. In the case of substantive clitic constructions, the clitic heading CIP is associated with an argument position of the verb, or stands for the non-verbal predicate selected by the copular verb, (22):

$$
\left.\left[\mathrm{CP} \ldots\left[\mathrm{CLP}_{[1,2,3 ; \mathrm{sg}, \mathrm{pl}]} \ldots \mathrm{Cl}_{\mathrm{vP}} \ldots[\mathrm{pro}] \ldots\right]\right]\right] \quad \text { (substantive clitics) }
$$

When a reflexive/reciprocal clitic or a non-reflexive clitic heads CIP, all the person and number values are available, and accusative or dative Case occur in correlation with the complement position associated with the clitic. In contrast, the nominative clitic, ' $s e$ ', exhibits 3pers.sg features and nominative Case, since the argument position related to the clitic corresponds to the constituent that ends up as the subject of the sentence.

Passive clitic 'se' only presents 3pers.sg features (see (23)). This clitic recovers the external argument of the verbal predicate, which it unaccusativizes. With Dobrovie-Sorin (1998) we consider that the latter property may be captured assuming that the clitic retains accusative.

$$
\left[\mathrm{CP} \ldots\left[\mathrm{CLP}_{\mathrm{C}} \mathrm{SE}_{[3 \mathrm{sg}, \mathrm{accus}]} \ldots\left[_{\mathrm{vP}}[\mathrm{pro}] \mathrm{v}[\mathrm{vP} \mathrm{V} \text { DP }]\right]\right]\right] \quad \text { (Passive clitic) }
$$

The same is also present in the ergative/unaccusative clitic, but no argument position is associated with it, (24). The ergative clitic presents the form of the reflexive clitic and occurs in all persons and numbers (see the example with the verb assustar 'to get scared' in (20), above).

$$
\left[\mathrm{CP} \cdots\left[\mathrm{CLP}_{\mathrm{C}} \mathrm{CL}_{[1,2,3 \mathrm{sg} \text {, accus] }}[\mathrm{vP} \mathrm{V} \text { DP }]\right]\right]
$$

(Ergative clitic)

Similarly, the inherent clitic exhibits every person and number form of the reflexive clitic and is not related to any argument position. However, it differs from the ergative clitic in that it does not function as a cue for the unaccusativity of the verb. Considering the inherent clitic may occur with verbs that do not license arguments in the accusative (cf. (21)), we assume 
that this clitic is not related to accusative or any other Case, being restricted to the spell-out of $\phi$-features, (25).

$$
\left[\mathrm { CP } \ldots \left[\mathrm{CLLP}_{[1,2,3 ; \mathrm{sg}, \mathrm{pl}]} \ldots\right.\right. \text { [vP ]]] (Inherent clitic) }
$$

The current approach differs from the one presented in Dobrovie-Sorin (1998) and Duarte and Matos (2000) in not assuming that all subtypes of clitics (both substantive and non-argumental ones) are merged inside $v \mathrm{P}$ prior to their cliticization onto their functional host. Instead we claim that all clitics are merged into the head of CIP, and are related to a position inside $\nu \mathrm{P}$, just in case they present argument or predicative content. In addition, we depart from Dobrovie-Sorin (1998) since we do not accept the claim that every clitic of the reflexive paradigm, but the nominative one, exhibits accusative Case. In fact, not only reflexives/reciprocals may check for dative Case, but also there is no evidence that the inherent clitic is related to any specific Case.

Summarizing, considering the core subtypes of clitics in Portuguese, we conclude the only property they all share is the spell-out of $\phi$-features.

\section{Enclisis and proclisis: a syntactic approach}

Our approach to pronominal clitic order will be a syntactic one. In other words, we will claim that enclisis and proclisis arise through Merge and Agree operations triggered by the usual requirements of matching and deletion of (un)interpretable formal features. Such operations are distinct from phonological operations of cliticization, which, as it is well known, apply to other linguistic forms besides pronominal clitics (see (7) above). Our syntactic approach to pronominal clitic placement will rely on the following assumptions:

(26) (i) The cliticization site is fixed and uniform across constructions and languages (see also Sportiche 1998, Schlonsky 2004); we will argue that the clitic node selects for AspP;

(ii) The clitic probes for $\phi$-features in the $v \mathrm{P}$ domain through Agree under local c-command;

(iii) Enclisis is the default option for clitic placement (see Duarte and Matos 1995, 2000): it is "a well defined syntactic configuration in which a host is adjoined to a clitic" (Schlonsky, 2004: 301); proclisis is a last resort option (see Duarte \& Matos 1995, 2000): "proclisis only obtains when enclisis is ruled out" (Schlonsky, 2004: 301). 
Elaborating on Rizzi (1993) and Schlonsky (2004), we will claim that enclisis obtains crosslinguistically when the verb moves at least as far as the cliticization site; we will also claim that part of the variation observed across languages derives from what we will call the Proclisis Parameter, stated in (27) below:

\section{Proclisis Parameter}

The $\phi$-features of pronominal clitics block Agree and Attract operations of the probe complete T: yes/no.

Under this view, enclisis and proclisis of pronominal clitics across languages are outcomes of the interplay of the Proclisis Parameter and of independently well established syntactic properties of each language: $e . g$., the value for the Split I Parameter and the targets of V-movement, matching requirements of functional nodes probing specific goals.

\subsection{The fixed position of the clitic node}

As shown in section 2, the clitic node may be associated with $\theta$-positions in the $\mathrm{V} / v$ domain.
a. O João disse-me isso. the João told-CL-dat-1sg that 'João told me that.'
b. O João disse-o à Maria. the João told-CL-accus-3sg to-the Maria 'João told it to Maria.'
c. Diz-se isso frequentemente. tells-CL-nom-3-sg that often

'One often tells that.'

In (28a), the first person clitic me is associated with the indirect object position, in (28b) the accusative clitic $o$ is associated with the direct internal argument one and in $(28 \mathrm{c})$ the nominative clitic $s e$ is associated with the external argument position. According to Chomsky (2001, 2004), the two first positions are internal to the VP domain, whereas the external argument is merged in Spec, $v \mathrm{P}$. Therefore, in order for the clitic to probe each of the relevant goals in (28), it must occupy a position above $v \mathrm{P}$ in the functional structure of the clause.

Departing from the minimal structure of the clause proposed in Chomsky (2000, 2001), we will adopt the idea that the first functional head above the $v \mathrm{P}$ domain is Asp (as in Borer 1995, Guéron 2000, Laca 2004, a.o.), a head which is the locus for the checking of telicity (see Jackendoff 1996) and of grammatical aspect. In making these assumptions, we take the view that AspP 
is the syntactic domain where the values for Aspect and Aktionsart are computed. ${ }^{6}$

So, the next question we must address is the position of the clitic node wrt the Asp projection. We will argue that the behaviour of participial clauses provides an answer to this question.

In most analysis, participial clauses, as well as past participles selected for by auxiliary verbs, are considered to be AspP domains (see Belletti 1990, Santos 1999, Demirdache and Extebarria 2000, a.o.), a view we also share. As it is well known, in participial clauses, pronominal clitics are ruled out in contemporary Romance languages ${ }^{7}$, as illustrated in (29)-(30).

a. Enviadas as flores ao vencedor do prémio, ... sent the flowers to-the winner of-the prize, ... 'Once the flowers sent to the winner of the prize...'

b. *Enviadas-lhe as flores, ... sent-Cl-dat-3sg the flowers, ...

(30) a. (Une fois) les fleurs envoyées au vainqueur du prix, ... (once) the flowers sent to-the winner of-the prize, ...

b. *(Une fois) les fleurs lui envoyées, ... (once) the flowers CL-dat-3sg, sent

The unavailability of pronominal clitics in participial clauses in EP, Spanish and French is straightforwardly accounted for if one assumes that the clitic node is merged above AspP, that is, if it is selected for by T. We thus expect clitics to be legitimate in $\mathrm{T}$ domains and illegitimate in Asp ones. The contrast between participial clauses and gerundive / infinitival ones, generally considered to be $\mathrm{T}$ domains, wrt pronominal clitic licensing argues in favour of this view (see the contrast between (29)-(30) and (31)-(32)).
a. Enviando-lhe as flores, ... sending-CL-dat-3-sg the flowers, ... 'Sending him/her the flowers, ...'

$\begin{array}{lll}\text { b. Ele decidiu enviar-lhe } & \text { as flores. } \\ \text { he decided } & \text { to-send- CL-dat-3sg } & \text { the flowers }\end{array}$ 'He decided to send him/her flowers.'

\footnotetext{
${ }^{6}$ Although some proposals suggest that $v \mathrm{P}$ is the domain of the eventuality description (Hale and Keyser 1993, Chomsky 1993, 1995, Schmitt 2001, a.o.), where most of the constituting elements of Lexical Aspect are specified, it is well known that Aktionsart and (Grammatical) Aspect interact. Thus, we assume that AspP is the core locus for the computation of Aspect and Aktionsart.

${ }^{7}$ The well known exception of Italian may be accounted for if we assume that, in this language, Asp has active properties and may host the clitic, the difference with BP being that in Italian there is generalized verb movement (see Belleti 1990), originating enclisis, whereas in BP the verb short-moves to Asp (see 3.3.).
} 
(32)
a. En
lui envoyant
les fleurs, ...
in CL-dat-3sg sending
the flowers, ...

'Sending him/her the flowers, ...'

$\begin{array}{llllll}\text { b. Il a décidé } & \text { de lui } & \text { envoyer les } & \text { fleurs. } \\ \text { he has-decided } & \text { of } & \text { CL-dat-3sg } & \text { to-send } & \text { the } & \text { flowers }\end{array}$ 'He decided to send him/her flowers.'

Summarizing, for Romance languages like EP, Spanish and French, we will assume the structure of the clause shown in (32), with the fixed position for the clitic node above AspP:

(33)
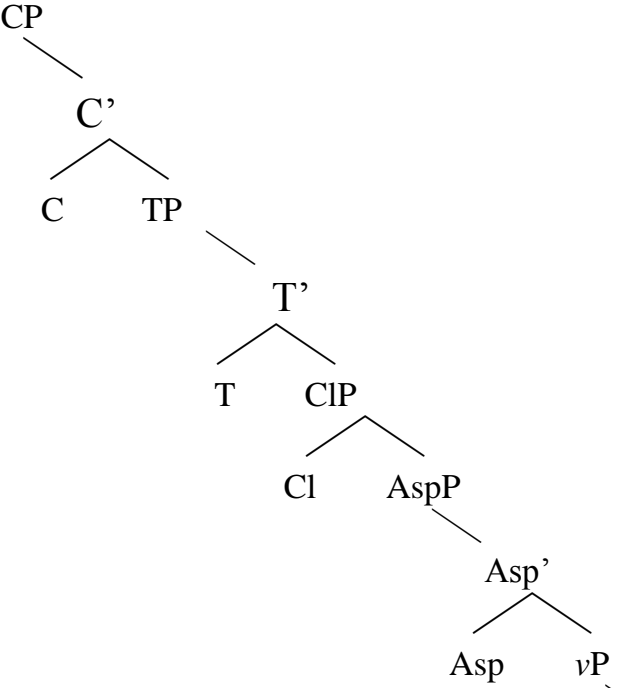

In a structure like (33), when $\mathrm{V}$ is attracted to $\mathrm{T}$, the default pattern is enclisis, with the intermediate steps $\mathrm{V}$-to- $v$-to-Asp-to-Cl, the normal $\mathrm{V}$-path. When the complex V-head left adjoins to the $\mathrm{Cl}$ head, the relevant feature of the clitic (call it V-host) is checked. ${ }^{8}$ Under this view, proclisis is a last resort

\footnotetext{
${ }^{8}$ We are assuming, according to the Minimalist Program and contra Baker (1988), that the order of morphemes internal to words is determined by morphological
} 
process, sensitive to the values fixed by different languages for the Proclisis Parameter.

\subsection{Enclisis and proclisis in languages fixing the value 'yes' for the Proclisis Parameter}

In languages like French, (standard) Italian and Spanish, which fix the value 'yes' for the Proclisis Parameter, when $\mathrm{T}$ is complete, that is, when it has uninterpretable $\phi$-features to be checked against the $\mathrm{V}$-complex, and hence is marked for deletion (Chomsky 2001, 2004), it attracts V. If a clitic is present, its $\phi$-features block the Agree operation that needs to take place between the probe $\mathrm{T}$ and the goal Asp/v/V. The relevant configuration is presented in (34).

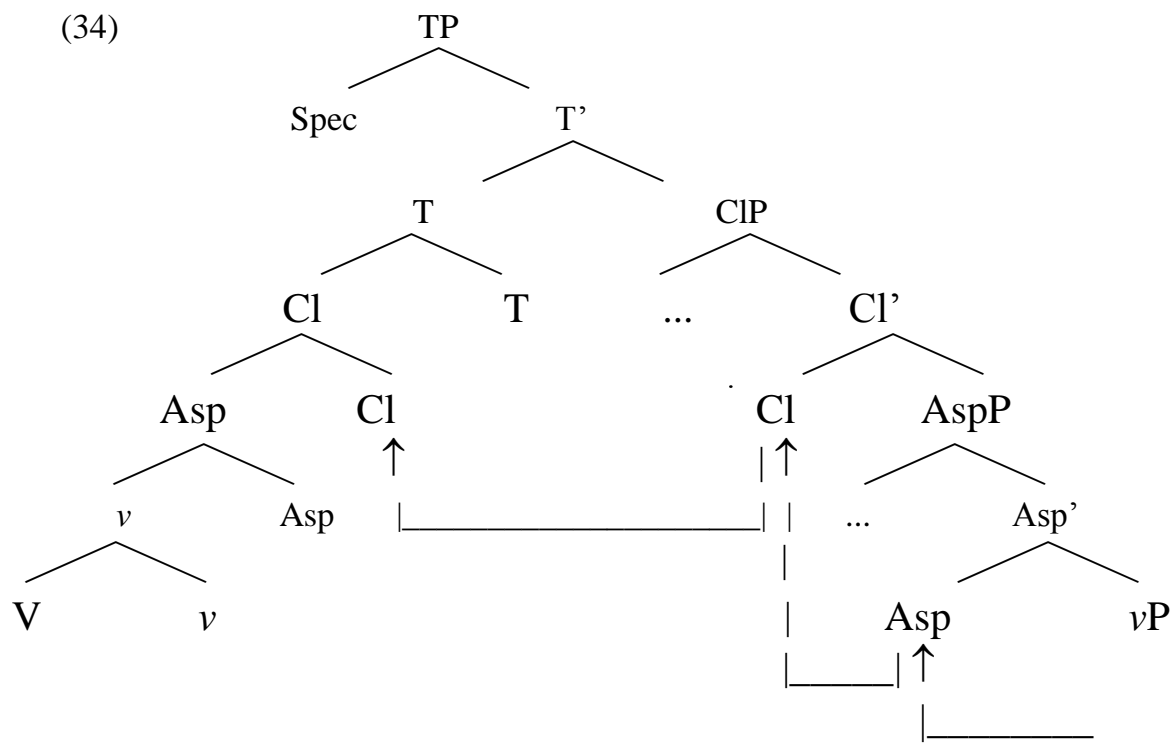

Since the uninterpretable $\phi$-features on T remain unchecked, the derivation crashes. As a last resort, an alternative derivation where the goal Asp/v/V moves to T skipping the clitic head makes it possible for the Agree operation between the probe $\mathrm{T}$ and its goal to be successful. Finally, the complex head $\mathrm{T} / \mathrm{Asp} / v / \mathrm{V}$ attracts the clitic and proclisis obtains. In this step of the derivation, the uninterpretable feature $\mathrm{V}$-host of the functional $\mathrm{Cl}$ head is checked against $\mathrm{V}$ and marked for deletion. The relevant configuration of the functional node $\mathrm{T}$ after Attract is presented in (35).

principles (Chomsky 1993, 1995, 2001, Halle and Marantz 1993, Harley and Noyer 2003, a.o.). Our analysis is compatible with this view, whether one considers that words enter the derivation fully inflected or that post-syntactic morphological rules fix the morpheme order. 
(35)

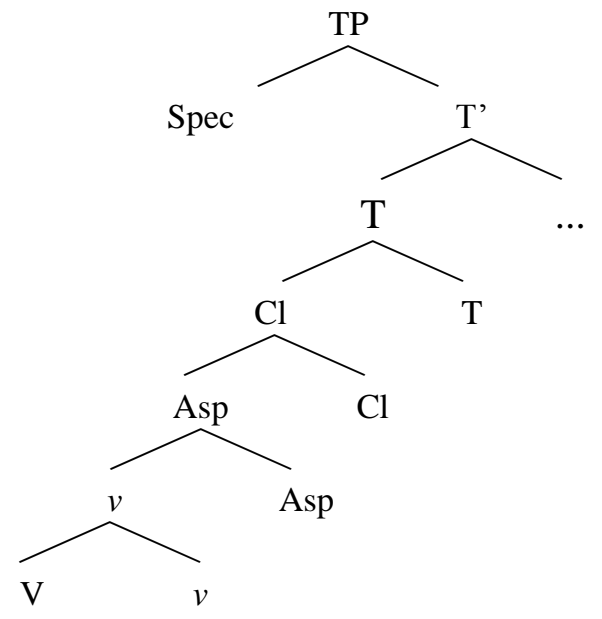

Instances of this configuration are sentences like those in (36).

(36)
a. Jean la
chante bien.
Jean
CL-accus-3sg-fem
sings well.
b. Gianni la
canta bene.
Gianni CL-accus-3sg-fem sings
well.
c. Juan
la canta
bién.
Juan CL-accus-3sg-fem well

'Jean/Gianni/Juan sings it well.'

In this type of languages when $\mathrm{T}$ is not complete, if non finite $\mathrm{T}$ attracts the V-complex - as it has been argued to be the case for (standard) Italian and Spanish (see Belletti 1990, Schlonsky 2004, a.o.) -, enclisis will obtain, being the default derivation (see (34) for the relevant configuration). Sentences like (37) illustrate the default derivation in (standard) Italian and Spanish.
a. Cantar la
me piace.

to-singCL-accus-3sg-fem CL-dat-1sg pleases

b. Me gusta cantar la.

CL-dat-1sg pleases to-sing-Cl-accus-3sg-fem

'It pleases me to sing it.'

However, if non complete $\mathrm{T}$ does not attract the $\mathrm{V}$-complex, and $\mathrm{V}$ does not move beyond Asp, a proclitic configuration may obtain, in which the clitic and the V-complex occupy two different head positions in Overt Syntax, provided the clitic locally c-commands the target of V-movement and adjacency conditions for phonological cliticization are met at the PA interface. 
Based on Pollock (1989)'s evidence for short V-movement in French infinitival clauses, we will consider that proclisis in French non finite clauses is a configuration of this type (see (38) and the examples in (39)).

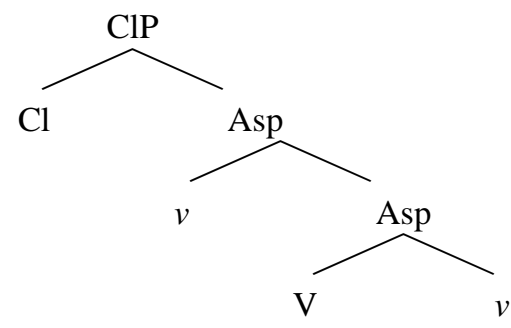

(39) a. Il faut ne pas le dire pour le moment. it needs not Cl-accus-3sg to-say for the moment 'It is necessary not to say it for the moment.'

b. Jean veut la voir demain. Jean wants $\mathrm{Cl}$-accus-3sg-fem to-see tomorrow 'Jean wants to see her tomorrow.'

3.3. Enclisis and proclisis in languages fixing the value 'no' for the Proclisis Parameter

Let us now consider what happens in languages fixing the value 'no' for the Proclisis Parameter. Based on data from Terzi (1999) and Schlonsky (2004), we claim that Cypriot Greek $^{9}$ and Berber belong to this group of languages (see (40)).

a. I Maria edhkiavasen to

(Terzi 1999:109) the Maria read CL-accus3sg-masc

'Maria read it.'

b. Yuzn-as-tt

Moh. (Schlonsky 2004: 338) sent-3sg CL-dat-3sg-CL-accus-3sg-fem Moћ

'Moh sent it to her.'

Based on evidence from Said Ali (1908), Epiphanio (1917), Duarte (1983), Madeira (1992), Rouveret (1999), Duarte \& Matos (1995, 2000), a.o., we also claim that EP belongs to this group pf languages (see (41)).

a. O João mandou-lhe a carta. the João sent-CL-dat-3sg the letter 'João sent him/her the letter.'

\footnotetext{
${ }^{9}$ In Cypriot Greek, enclisis also occurs in finite embedded sentences (Terzi 1999: 109).
} 

b. A Maria zangou-se. the Maria got-angry-CL-accus-3sg 'Maria got angry.'

As it is well known, proclisis in EP is triggered by operator-like elements, such as $w h$-phrases, quantified subjects, complementizers, sentential negation, focusing and aspectual adverbs (see (42)); a similar phenomenon happens in Cypriot Greek ${ }^{10},(43)$, and in Berber, (44):

a. O João não the mandou a carta. the João not CL-dat-3sg sent the letter 'João did not send him/her the letter.'

b. Acho que a Maria se zangou. think that the Maria CL-accus-3sg got-angry 'I think that Maria got angry.'
a. En ton
NEG CL-acc-3sg-masc know
iksero. 'I know him.'
b. Telo na ton do want-1sg M CL-acc-3sg-masc see-1sg
c. Pjos ton idhe? who CL-3-sg-masc saw
'Who saw him?'

(Terzi 1999: 110)

(44) Ur as-tt-yuzin not CL-dat-3sg-CL-acc-3sg-fem sent-3sg Moh

'Moh did not send it to her.'

In the absence of these triggering elements, enclisis obtains. In other words, enclisis is the default pattern for clitic placement, irrespective of the finite/non-finite divide (see (45)), in inflected infinitival domains, where $\mathrm{T}$ is complete, and (46) in non inflected infinitival domains where $\mathrm{T}$ is incomplete but active.

(45) a. Os editores lamentaram [os autores enviarem-lhes (poucos) the editors regretted the authors to-send-3pl-CL-dat-3pl few manuscritos]. manuscripts

'The editors regretted that the authors send them few manuscripts.'

10 According to Terzi (1999: 110), proclisis is triggered in the presence of a preceding Negation, subjonctif particle or Focus head. 
b. Os editores lamentaram [os autores não lhes enviarem the editors regretted the authors not CL-dat-3pl to-send-3pl manuscritos]. manuscripts

'The editors regretted that the authors do not send them manuscripts.'

a. Os editores quiseram [enviar-lhes os manuscritos]. the editors wanted to-send-CL-dat-3pl the manuscripts 'The editors wanted to send them the manuscripts.'

b. Os editores quiseram [não lhes enviar os manuscritos]. the editors wanted not CL-dat-3pl send the manuscripts 'The editors wanted not to send them the manuscripts.'

Summarizing, the distribution of enclisis and proclisis behave alike in finite and non-finite domains, except for the non-finite contexts where clitics are ruled out (e.g., participial clauses and participle and gerund domains selected for by auxiliary verbs, see (47)-(49) $)^{11}$, due to the properties of the embedded functional domain.

a. Alertados os doentes para os riscos da gripe, ... alerted the patients to the risks of-the influenza,... 'The patients being alerted to the risks of influenza, ...'

b. *Alertados-os para os riscos da gripe alerted-CL-acc-3pl-masc to the risks of-the influenza, ...

(48) a. Os médicos têm [alertado os doentes para os riscos 'The doctors have alerted the patients to the risks da gripe]. of influenza.'

b. Os médicos têm-nos [alertado para os the doctors have-CL-acc-3pl-masc alerted to the riscos da gripe]. risks of-the influenza

'The doctors have alerted them to the risks of-the influenza.'

11 Again due to defective properties of functional heads in embedded domains, Clitic Climbing must occur in Reestructuring and Clause Union contexts, see (i)-(ii).

\begin{tabular}{l} 
(i) (O conferencista,) os professores querem-no [apresentar \\
\hline
\end{tabular} (the speaker,) the teachers want-CL-acc-3sg-masc to-introduce aos alunos].

to the students

'(The speaker), the teachers want to introduce him to their students.'

(ii) $\mathrm{O}$ treinador mandou-os correr.

the coach made-CL-acc-3pl-masc run

'The coach made them run.' 
c. *Os médicos têm [alertado-os para os the doctors have alerted-CL-acc-3pl-masc to the riscos da gripe].

risks of-the influenza

(49) a. Durante o treino, o capitão ia [alertando os during the training, the captain went alert-GER the soldados para os riscos que corriam]. soldiers to the risks that ran-3pl

'During the training the captain was making the soldiers aware of the risks they were taking.'

b. Durante o treino, o capitão ia-os [alertando during the training, the captain went-CL-acc-3pl-masc alert-GER para os riscos que corriam]. to the risks that ran-3pl

'During the training the captain was making them aware of the risks they were taking.'

c. *Durante o treino, o capitão ia [alertando-os during the training, the captain went alert-GER-CL-acc-3pl-masc para os riscos que corriam]. to the risks that ran-3pl

To account for this distribution, the crucial idea behind our analysis is as follows: in languages that fix the value 'no' for the Proclisis Parameter, the $\phi$-features of the clitic do not intervene between the head $\mathrm{T}$ and the complex Asp- $v$-V, but they intervene $(i)$ between c-commanding heads probing active $\mathrm{T}$ and active $\mathrm{T}$ goals and (ii) between active $\mathrm{T}$ probing and attracting goals related to its temporal features. In other words, the Proclisis Parameter formalizes the following property: $\mathrm{T}$ being a bundle of features consisting of two subarrays, temporal features (the V-features in Chomsky 1995) and $\phi$ -features, languages differ wrt the specific subarray sensitive to the $\phi$-features of pronominal clitics. So, in languages fixing the value 'no' for the Proclisis Parameter, if the clitic intervenes in the $\mathrm{V}$-path when matching of temporal features of the complex T-Asp- $v-\mathrm{V}$ with other heads is at stake, proclisis is the last resort for the derivation to survive.

Illustrating this analysis with some cases where proclisis is the obligatory pattern for clitic placement in standard $\mathrm{EP}$, simple (que, se, para) and complex complementizers marked for finiteness (e.g., porque, embora) and nonfiniteness (e.g., antes de, apesar de) and those specified with the feature [+wh] or [+focus] (é que) probe for active $\mathrm{T}$ for matching of temporal features; if the default enclitic derivation obtains, the clitic $\phi$-features block the Agree operation and the derivation crashes; the same happens with empty 
$\mathrm{C}$ merged with the features $[+\mathrm{wh}, \pm \mathrm{Q}]^{12}$. So, proclisis is the last resort for clitic placement in subordinate clauses headed by simple and complex complementizers, in wh-clauses and in clefts.

Proclisis is also obligatory when unselective binders that involve either quantification over events or implicit temporal relations probe for the temporal features of $\mathrm{T},(50)$.

(50) a. O João já laindal também /sempre me telefonou the João already/ still / also /indeed CL-dat-1sg called (hoje).

(today)

'João already/still/also/indeed called me (today).'

b. *O João já lainda /também/sempre telefonou-me (hoje). the João already /still /also /indeed called-CL-dat-1sg (today)

When $\mathrm{T}$ probes and attracts operator-like heads and phrases, the clitic $\phi$-features also block the Attract operation and proclisis is the last resort for the derivation to survive, $(51)-(53) .^{13}$

(51)

a. O João não me telefonou hoje. the João not CL-dat-1sg called today. 'João did not call me today.'

b. *O João não telefonou-me hoje. the João not called-CL-dat-1sg today.

(52) a. Todos os meus amigos/Poucos amigos me telefonaram all the my friends/ few friends CL-dat-1sgcalled hoje. today 'All my friends / Few friends called me today.'

b. *Todos os meus amigos / Poucos amigos telefonaram-me all the my friends / Few friends called-CL-dat-1sg hoje. today

12 In particular, empty $\mathrm{C}$ with the features $[+w h,+Q]$ agrees with and attracts $\mathrm{T}$ (see Ambar 1992).

13 When $\mathrm{T}$ probes and agrees with operator- like elements, two situations are possible: (i) Attract of the goal is obligatory (this is the case when the goal is the sentential negation marker, according to the analysis of Pollock 1989); or (ii) Attract only occurs if a specific uninterpretable feature in $\mathrm{T}$ is present (this is what happens to subject quantifier phrases when the EPP feature of $\mathrm{T}$ is present). 
a. Só /apenas/mesmo /até o João me telefonou only / just / even / even the João CL-dat-1sg called hoje. today.

'Only/just/even João called me today.'

b. *Só / apenas/mesmo / até o João telefonou-me hoje. only / just / even / even the João called-CL-dat-1sg today.

Notice that when the temporal features of $\mathrm{T}$ probe and agree with (but do not attract) unselective binders and other operator-like heads and phrases, the clitic $\phi$-features do not block the operation Agree, $(54)^{14}$.

a. O João telefonou-me já / também.

The João called-CL-dat-1sg already / also

'João already/also called me.'

b. Telefonaram-me todos os meus amigos/ poucos called-3pl-CL-dat-1sg all the my friends/ few amigos hoje.

friends today

'All my friends / few friends called me today.'

Summarizing: in languages fixing the value 'no' for the Proclisis Parameter, like EP, enclisis is the general pattern for clitic placement, since the $\phi$-features of pronominal clitics do not block Agree and Attract operations driven by the $\phi$-features of complete T. However, in this type of languages, the $\phi$-features of pronominal clitics block (i) Agree operations probing the subarray of temporal features in $\mathrm{T}$ and (ii) Attract operations of probe $\mathrm{T}$ driven by its temporal features. Therefore, in those contexts where such operations must apply, proclisis is the last resort for clitic placement.

\subsection{Enclisis and proclisis in $B P$}

Quantitative studies based on extensive oral corpora show that in BP proclisis is the preferred option (Cyrino 1990, Corrêa 1991, Galves and Abaurre 1996, a.o). However, in the written corpus we analysed ${ }^{15}$, the striking property found in the data is free choice between enclisis and proclisis, independently of the local syntactic context, (55)-(57), exception made to sentential initial position of root clauses, where proclisis does not occur. ${ }^{16}$

${ }^{14} \mathrm{We}$ assume that this is so, because, due to the Earliness Principle, Agree applies as soon as $\mathrm{T}$ is merged in the derivation, that is, before the $\mathrm{V}-\mathrm{Cl}$ complex moves to $\mathrm{T}$.

15 The corpus consists of advertisements in magazines (Cláudia and Veja) and newspapers (Jornal do Brasil), opinion articles in Jornal do Brasil and readers' letters in the Época magazine.

16 As proclisis is found in sentential initial position of root clauses in oral corpora, the restriction we found in the written corpus should not be taken as evidence for the 
(55) Root sentences

a. a Nestlé me ajuda muito. (Cláudia, Junho 1999: 32-33) the Nestlé CL-acc-1sg helps a-lot

'Nestlé helps me a lot.'

b. o sucesso subiu-lhe

à cabeça.

(Época, 103/2000)

the success climbed-up-CL-dat-3sg to-the head

'Success went to his head.'

(56) Finite embedded domains

a. O governador Joaquim Roriz persegue [quem se opõe the governor Joaquim Roriz persecutes [whoever CL-3sg opposes a seus desmandos].

to his abuses

'Governor Joaquim Roriz persecutes [whoever is against his abuses].'

(Época, 107/2000)

b. é possível estimular um bebê [para que, no futuro, is possible stimulate a baby [for that, in the future, torne-se um bom aluno] become-CL-3sg a good student]

'It is possible to stimulate a baby so that he will become a good student.'

(Época, 103/2000)

(57) Nonfinite embedded domains

a. Nenhum outro carro faz [você se sentir tão no other car makes [you CL-3sg feel so

bem em casa].

well at home

'No other car makes you to feel so well at home.'

(Cláudia, Junho 1999: 57)

b. Acabei [de tornar-me assinante da Época]. (Época, 106/2000)

finished to become-CL-1sg subscriber of the Época 'I have just become a subscriber of Época.'

This kind of data suggest that there is some conflict between the Grammar of $\mathrm{BP}$ resulting from the language acquisition process and the educated written pattern. We will concentrate on the first one, presumably the innovative grammar.

claim that the BP Grammar obeys the Tobbler-Mussafia law; instead, we take it as the result of a learned normative rule. 
According to our analysis, BP belongs to the group of languages that fix the value 'yes' for the Proclisis Parameter, together with Spanish, (standard) Italian and French. The high frequency of proclisis found in the data referred to above is, thus, predicted.

The most striking property of the innovative grammar of BP is the loss of Clitic Climbing in infinitival domains selected for by control verbs that, in EP, may form complex predicates, (58) vs. (59).

(58) Os cariocas vão querer me matar. (Domingo, 24.10.1999) (*EP) the cariocas go want CL-acc-1sg kill

'Cariocas will want to kill me.'

(59) Os cariocas vão-me querer matar / Os cariocas vão the cariocas go-CL-acc-1sg want kill / the cariocas go querer matar-me. want kill-CL-acc-1sg 'Cariocas will want to kill me.'

The loss of Clitic Climbing in verbal sequences headed by auxiliary verbs, obligatory in EP, is also extensively observed in BP, (60) vs. (61).
a. Eles tinham certamente me
visto no Calçadão.
$(\checkmark \mathrm{BP} ; * \mathrm{EP})$
they had certainly CL-acc- $1 \mathrm{sg}$ seen at-the Calçadão
'They certainly had seen me at Calçadão.'
b. Ele foi certamente the apresentado por Maria.
$(\checkmark \mathrm{BP} ; * \mathrm{EP})$
he was certainly CL-dat- $1 \mathrm{sg}$ introduced by Maria
'He certainly was introduced to him/her by Mary.'

(61)
a. Eles tinham-me
certamente visto no
Calçadão.
they had-CL-acc-1sg certainly seen at-the Calçadão. 'They certainly had seen me at Calçadão.'
b. Ele foi-lhe certamente apresentado pela Maria. $(* \mathrm{BP} ; \sqrt{\mathrm{EP}})$
he was-CL-dat-3sg certainly introduced by-the Maria 'He certainly was introduced to him/her by Mary.'

Furthermore, non-finite domains selected for by semi-auxiliary verbs, present extensively proclisis to the embedded (gerund or infinitive) verb, (62), contrary to what happens in EP, where depending on the formation of a complex predicate, the clitic is attracted to the tensed verb or enclitic to the embedded infinitive form, (63). 
(62)

a. Ele está certamente te procurando. $(\checkmark \mathrm{BP} ; * \mathrm{EP})$

he is certainly CL-acc-2sg,looking for

'He is certainly looking for you.'

b. Muita gente da Vila Isabel começou a me visitar.

$(\checkmark \mathrm{BP} ; \mathrm{EP})$

many people from-the Vila Isabel began to CL-acc-1sg visit 'Many people from Vila Isabel started visiting me.'

(Domingo, 31.10.1999)

c. (...) dois destinos podem se cruzar e acabar two destinies may CL-acc-3pl cross and end

em fatalidade. ( $\quad$ BP; *EP)

in fatality

'Two destinies may cross each other and end up in fatality.'

(Época, 109/2000)

(63) a. Ele está certamente a procurar-te.

he is certainly to look-CL-acc-2sg for

'He is certainly looking for you.'

b. Muita gente da Vila Isabel começou(-me) a visitar(-me).

$(\checkmark \mathrm{EP})$

many people from-theVila Isabel began(-CL1sg) to visit-CL1sg 'Many people from Vila Isabel started visiting me.'

c. (...) dois destinos podem(-se) cruzar(-se) e acabar two destinies may(-CL-3pl) cross(-CL-3pl) and end em fatalidade.

$(\sqrt{\mathrm{EP}})$

in fatality

'Two destinies may cross each other and end up in fatality.'

These data are directly accounted for by our analysis, with some extra assumptions about clause structure of non-finite domains in BP, which can be stated as follows: economy of derivations in embedded domains is higher rated than economy of representations (Gonçalves and Duarte 2001) ${ }^{17}$. This means that BP favours active functional nodes in non-finite domains, thus allowing Agree to operate within the embedded domain and delete the relevant uninterpretable features. This property, we claim, has wide empirical repercussions, namely, in the licensing of VP ellipsis (Cyrino and Matos 2002, this volume), the preference for the non-formation of complex predicates (Gonçalves and Duarte 2001), and the proclitic pattern referred to above.

What are the consequences of the above mentioned property for clause structure of non-finite domains in BP? At first glance, the extensive proclitic pattern in the innovative Grammar of BP suggests that this language is similar

17 For the claim that functional heads count for economy of representations, see Bošković (1997), a.o. 
to French (see (39)). However, contrasts like those in (64)-(65) show that this is not the case (see Pagotto 1993, Cyrino 1993).

a. Eles tinham certamente me visto no Calçadão.

$(\checkmark \mathrm{BP})$

they had certainly CL-acc-1sg seen at-the Calçadão

'They certainly had seen me at Calçadão.'

b. Elefoi certamente lhe apresentado por Maria.

he was certainly CL-dat-1sg introduced by Maria

'He certainly was introduced to him/her by Mary.'

(65)

$\begin{array}{lllll}\text { a. Ils m'avaient } & \text { certainement } & \text { vu } & \text { au } & \text { Calçadão. } \\ \text { they CL-acc-1sg had } & \text { certainly } & \text { seen } & \text { at-the Calçadão } \\ \text { /*Ils avaientcertainement } m e & \text { vu } & \text { au } & \text { Calçadão. }\end{array}$

/*They had certainly CL-acc-1sg seen at-the Calçadão

b. Il lui a été certainement présenté par Maria.

he CL-dat-3sg was certainly introduced by Maria

/ *Il a été certainement lui présenté par Maria.

/ *He was certainly CL-dat-3sg introduced by Maria

Notice that the contrast between BP and French wrt licensing of clitics in participial embedded domains is "neutralized" in negative contexts: that is, neither BP nor French allow sentential negation in these contexts, (66)-(67) (see Matos and Cyrino 2001, Cyrino and Matos, this volume).

(66)
a. *Eles tinham não visto Pedro no Calçadão. they had not seen Pedro at-the Calçadão
b. *Ele foi não apresentado a Pedro por Maria. he was not introduced to Pedro by Maria
a. *Ils avaient ne pas vu Pedro au Calçadão. They had not seen Pedro at-the Calçadão
b. *Il a été ne pas présenté à Pedro par Maria.
He was not introduced to Pedro by Maria

We take the fact that sentential negation is not licensed as evidence for the absence of $\mathrm{T}$ in these participial domains. Hence, the difference between French and the innovative grammar of BP lies in the absence vs. the presence of an active Asp node in complement participial domains. The similarity lies in the fact that, in general, in non finite domains, the verb, for independent reasons, does not move beyond Asp, thus yelding the proclitic pattern. 


\section{Concluding remarks}

In this paper, we argued that the categorial status of pronominal clitics is better accounted for if they are conceived as defective functional heads, consisting of a bundle of $\phi$-features, as proposed in Déchaine and Wiltschko (2002).

This characterization of pronominal clitics allows us to capture the strictly functional properties of some clitics and the relationship they establish with the targets of $\mathrm{V}$ movement ( $\mathrm{T}$ and Asp), a relationship that favours a syntactic approach to clitic placement. Furthermore, a natural consequence of this proposal is the claim that the clitic is merged in a fixed position in the clause structure, above the Asp node.

Since the clitic intervenes in the V-path, it is expected that Agree involving the sub-array of $\phi$-features of $\mathrm{T}$ and $\mathrm{V}$ be sensitive to the presence of the clitic, itself a $\phi$-feature bundle. In our analysis, this sensitivity is expressed as the Proclisis Parameter. When languages set the value 'yes' for this parameter, proclisis is the obligatory pattern in finite sentences, since the $\phi$-features of the clitic block Agree between complete $\mathrm{T}$ and $\mathrm{V}$; in these languages, the clitic order pattern found in non-finite clauses depends on whether $\mathrm{V}$ targets non complete $\mathrm{T}$. On the contrary, in languages setting the value 'no' for this parameter, enclisis dominantly occurs, since the $\phi$-features of the clitic do not block Agree and Attract between complete T and V. However, in these languages, enclitics in $\mathrm{T}$ block Agree probing the sub-array of V-like features of $\mathrm{T}$ and Attract by probe $\mathrm{T}$ of quantified XPs; in such contexts proclisis arises as a last resort.

Wrt to the microvariation between EP and BP, we have argued that the innovative grammar of BP sets the value 'yes' for the Proclisis Parameter, together with Spanish, (standard) Italian and French, whilst EP, together with languages like Berber and Cypriot Greek, sets the value 'no' for the same parameter.

Other differences between Romance languages and, specifically, EP and $\mathrm{BP}$, are accounted for by the properties of the nodes $\mathrm{T}$ and Asp, namely, their ability to attract $\mathrm{V}$ and or to check uninterpretable features through Agree without Attract.

Two final remarks concern theoretical issues. The analysis we have proposed provides additional empirical support to the claim made in Chomsky (2000, 2001, 2004) that V-like features and $\phi$-features of $V$ are located in the same functional node, $\mathrm{T}$. It also enhances the theoretical import of the concept of parameter, since, in what concerns clitic order patterns, the Proclisis Parameter captures variation that cuts across genetic and typological language groups.

\section{Acknowledgements}

We thank the audience of the 2nd Workshop of the Research Project Português Europeu, Português Brasileiro, held in the Universidade Federal 
do Ceará, for valuable comments on a previous version of this work. We thank in particular Mary Kato and João Peres, for their comments and suggestions on the current paper, and Sonia Cyrino and Flaviane Fernandes for their judgements on BP data.

\section{References}

Ambar, M. (1992) Para uma Sintaxe da Inversão Sujeito-Verbo em Português. Lisboa: Colibri.

Beletti, A. (1982) 'Morphological' Passive and pro-Drop: the Impersonal Construction in Italian, Journal of Linguistic Research, 2, 1-34.

Beletti, A. (1990) Generalized Verb Movement - Aspects of Verb Syntax. Torino: Osenberg \& Sellier.

Borer, H. (1995) The ups and downs of Hebrew Verb Movement, Natural Language and Linguistic Theory, 13, 527-606.

Bošković, Z. (1997) The Syntax of Non-Finite Complementation: An Economy Approach. Cambridge, Mass.: The MIT Press.

Chomsky, N. (1981) Lectures on Government and Binding. Dordrecht: Foris.

Chomsky, N. (1993) A Minimalist Program for Linguistic Theory. In The View from Building 20: Essays in Linguistics in Honor of Sylvain Bromberger (K. Hale \& S. Keyser, editors). Cambridge, Mass.: The MIT Press.

Chomsky, N. (1995) The Minimalist Program. Cambridge, Mass.: The MIT Press.

Chomsky, N. (2000) Minimalist Inquiries: the Framework. In Step By Step: Essays on Minimalist Syntax in Honor of Howard Lasnik (R. Martin, D. Michaels \& J. Uriagereka, editors). Cambridge, Mass.: The MIT Press.

Chomsky, N. (2001) Derivation by Phase. In Ken Hale: a Life in Language (M. Kenstowicz, editor). Cambridge, Mass.: The MIT Press.

Chomsky, N. (2004) Beyond Explanatory Adequacy. In Structures and Beyond: the Cartography of Syntactic Structures, vol. 3. (A. Belletti, editor). New York: Oxford University Press.

Cinque, G. (1988) On si Constructions and the Theory of arb, Linguístic Inquiry, 19, 521-581.

Corrêa, V. (1991) O Objeto Direto Nulo no Português do Brasil. MA dissertation, UNICAMP.

Cyrino, S. (1990) O Objeto Nulo no Português do Brasil: uma Mudança Paramétrica?. Campinas: UNICAMP.

Cyrino, S. (1993) Observações sobre a Mudança Diacrônica no Português do Brasil: Objecto Nulo e Clíticos. In Português Brasileiro - Uma viagem diacrônica (I. Roberts \& M. Kato, editors). Campinas: Editora da Universidade Estadual de Campinas.

Cyrino, S. \& Matos, G. (2002) VP Ellipsis in European and Brazilian Portuguese.: a comparative analysis, Journal of Portuguese Linguistics, 1, 177-214.

Cyrino, S. \& Matos, G. (this volume) Local licensers and recovering in VP ellipsis construction: variation across languages and language varieties.

Déchaine, R. -M. \& Wiltschko, M. (2002) Decomposing Pronouns, Linguistic Inquiry, 33, 409-442. 
Demirdache, H. \& Uribe-Etxberria, M. (2000) The Primitives of Temporal Relations. In In Step By Step: Essays on Minimalist Syntax in Honor of Howard Lasnik (R. Martin, D. Michaels \& J. Uriagereka, editors). Cambridge, Mass.: The MIT Press.

Dobrovie-Sorin, C. (1998) Impersonnal "Se" Constructions in Romance and the Passivization of Unergatives, Linguistic Inquiry, 29, 399-437.

Duarte, I. (1983) Variação Paramétrica e Ordem dos Clíticos, Revista da Faculdade de Letras, Número especial comemorativo do $50^{\circ}$ da $R F L, 158-178$.

Duarte, I. \& Matos, G. (1995) A colocação dos Clíticos no Português Europeu e a Hipótese Minimalista, Actas do X Encontro Nacional da Associação Portuguesa de Linguística, pp. 177-193. Lisboa: Associação Portuguesa de Linguística.

Duarte, I. \& Matos, G. (2000) Romance Clitics and the Minimalist Program. In Portuguese Syntax. New Comparative Studies (J. Costa, editor). Oxford: Oxford University Press.

Duarte, I., Matos, G.\& Faria, I. (1995) Specificity of European Portuguese Clitics in Romance. In Studies in the Acquisition of Portuguese (I. Faria \& M. J. Freitas, editors). Lisboa: Colibri / Associação Portuguesa de Linguística.

Epiphanio da Silva Dias, A. (1917) Syntaxe Histórica Portuguesa. Lisboa: Livraria Clássica Editora, $5^{\text {th }}$ ed., 1970.

Ernout, A. \& Thomas, F. (1951) Syntaxe Latine. Paris: Éditions Kincksieck, $2^{\text {nd }}$ ed., 1953.

Galves, C. (2000) Agreement, Predication and Pronouns in the History of Portuguese. In Portuguese Syntax. New Comparative Studies (J. Costa, editor). Oxford: Oxford University Press.

Galves, C. \& Abaurre, M. B. (1996) Os Clíticos no Português Brasileiro: Elementos para uma Abordagem Sintáctico-Fonológica. In Gramática do Português Falado, vol. IV (A. Castilho \& M. Basílio, editors). Campinas: Editora da UNICAMP/FAPESP.

Gonçalves, A. (1999) Predicados Complexos Verbais em Contextos de Infinitivo não Preposicionado do Português Europeu. PhD Dissertation, Universidade de Lisboa.

Gonçalves, A. \& Duarte, I. (2001) Construções Causativas em Português Europeu e Português Brasileiro. In Actas do XVI Encontro Nacional da Associação Portuguesa de Linguística (C. Nunes Correia \& A. Gonçalves, editors), pp. 657-671. Lisboa: Associação Portuguesa de Linguística.

Guéron, J. (2000) On the syntactic domains of temporal interpretation. In Traiani Augusti vestigia sequamur: studia ligvistica in honorem Lilianae Tasmowsky (M. Coene, W. D. Culder, P. Dendale, \& Y. D’hust, editors). Padua: Unipress.

Guéron, J. (2004) Tense Construal and the Argument Structure of Auxiliaries. In The Syntax of Time (J. Guéron \& J. Lecarme, editors). Cambridge, Mass.: The MIT Press.

Jaeggli, O. (1982) Topics in Romance Syntax. Dordrecht: Foris.

Jackendoff, R. (1996) The Proper Treatment of Measuring out, Telicity, and perhaps even Quantification in English, Natural Language and Linguistic Theory, 14, 305-354 .

Kayne, R. (1991) Romance Clitics, Verb Movement and Pro, Linguistic Inquiry, 22, 647-686.

Kayne, R. (1994) The Antisymmetry of Syntax. Cambridge, Mass.: The MIT Press.

Hale, K. \& Keyser, S. (1993) On the Argument Structure and the Lexical expression of Syntactic Relations. In The View from Building 20: Essays in Linguistics in Honor 
of Sylvain Bromberger (K. Hale \& S. Keyser, editors). Cambridge, Mass.: The MIT Press.

Halle, M. \& Marantz, A. (1993) Distributed Morphology and the Pieces of Inflection. In The View from Building 20: Essays in Linguistics in Honor of Sylvain Bromberger (K. Hale \& S. Keyser, editors). Cambridge, Mass.: The MIT Press.

Harley, H. \& Noyer, R. (2003) Distributed Morphology. In The Second Glot International State-of-the-Article Book (L. Cheng \& R. Sybesma, editors). Berlin and New York: Mouton de Gruyter.

Laca, B. (2004) Romance "Aspectual" Periphrases: Eventuality Modification versus "Syntactic" Aspect. In The Syntax of Time (J. Guéron \& J. Lecarme, editors) Cambridge, Mass.: The MIT Press.

Madeira, A. M. (1992) On Clitic Placement in European Portuguese University College of London Working Papers in Linguistics, 4.

Martins, A. M. (1994) Clíticos na História do Português. PhD Dissertation, Universidade de Lisboa.

Matos, G. \& Cyrino, S. (2001) Elipse do VP no Português Europeu e no Português Brasileiro. In Boletim da Associação Brasileira de Linguística, v. 26 (M. E. Soares, editor), pp. 386-390. Número especial: II Congresso Internacional da Abralin, Fortaleza, Março de 2001 - Anais - vol. I, Fortaleza.

Nunes, J. (1990) O famigerado se. MA dissertation, UNICAMP.

Nunes, J. (1993) Direção de Cliticização, Objeto Nulo e Pronome Tónico na Posição de Objeto em Português Brasileiro. In Português Brasileiro - Uma viagem diacrônica (I. Roberts \& M. Kato, editors). Campinas: Editora da Universidade Estadual de Campinas.

Otero, C. (1996) Head Movement, Cliticization, Precompilation and Word Insertion (Comments on Uriagereka's paper). In Current Issues in Comparative Grammar (R. Freidin, editor). Dordrecht: Kluwer.

Pagotto, E. (1993) Clíticos, Mudança e Selecção Natural. In Português Brasileiro Uma viagem diacrônica (I. Roberts \& M. Kato, editors). Campinas: Editora da Universidade Estadual de Campinas.

Pollock, J. -Y. (1989) Verb Movement, Universal Grammar and the Structure of IP, Linguistic Inquiry, 20, 185-206.

Postal, P. (1966) On So-Called "Pronouns" in English. In Modern Studies in English (D. Reibel \& S. Schane, editors). Englewood Cliffs, N.J.: Prentice-Hall.

Raposo, E. P. \& Uriagereka, J. (2005) Clitic Placement in Western Iberian: a Minimalist View. In The Oxford Handbook of Comparative Syntax (G. Cinque \& R. Kayne, editors). Oxford: Oxford University Press.

Rizzi, L. (1993) Some Notes on Romance Cliticization. Published in L. Rizzi (2000) Comparative Syntax and Language Acquisition. London/New York: Routledge.

Rouveret, A. (1999) Clitics, Subjects and Tense in European Portuguese. In Clitics in the Languages of Europe (H. van Riemsdijk, editor). Berlin: Mouton de Gruyter.

Said Ali, M. (1908) Dificuldades da Língua Portuguesa. Rio de Janeiro/São Paulo: Laemmert e C.

Santos, A. L. (1999) O Particípio Absoluto em Português e em outras Línguas Românicas. MA dissertation. Lisboa: Faculdade de Letras da Universidade de Lisboa. 
Schlonsky, U. (2004) Enclisis and Proclisis. In The Structure of $C P$ and IP. The Cartography of Syntactic Structures. Vol.2 (L. Rizzi, editor). Oxford: Oxford University Press.

Schmitt, C. (2001) Cross-Linguistic Variation and the Present Perfect: the Case of Portuguese, Natural Language and Linguistic Theory, 19, 403-453.

Sportiche, D. (1998) Partitions and Atoms of Clause Structure - Subjects, Agreement, Case and Clitics. London/New York: Routledge.

Terzi, A. (1999) Clitic Combinations, Their Hosts and Their Ordering, Natural Language and Linguistic Theory, 17, 85-121.

Uriagereka, J. (1996) Determiner Clitic Placement. In Current Issues in Comparative Grammar (R. Freidin, editor). Dordrecht: Kluwer.

Vigário, M. (1999) Pronominal Cliticization in European Portuguese: a post-lexical operation, Catalan Working Papers in Linguistics, 7, 219-237.

Vigário, M. (2001). The Prosodic Word in European Portuguese. PhD Dissertation, Universidade de Lisboa.

Vincent, N. (1988) Latin. In The Romance Languages (M. Harris \& N. Vicent, editors). London: Croom Helm.

Zwicky, A. (1977) On Clitics. Bloomington, Indiana: Indiana Linguistics Club.

\section{Inês Duarte}

Dept. de Linguística Geral

e Românica \& Onset-CEL,

Faculdade de Letras da

Universidade de Lisboa

Alameda da Universidade 1600-214 Lisboa

Portugal

aij@mail.telepac.pt
Gabriela Matos

Dept. de Linguística Geral

e Românica \& Onset-CEL,

Faculdade de Letras da

Universidade de Lisboa

Alameda da Universidade 1600-214 Lisboa

Portugal

mgabrielamatos@yahoo.co.uk
Anabela Gonçalves Dept. de Linguística Geral e Românica \& Onset-CEL, Faculdade de Letras da Universidade de Lisboa Alameda da Universidade 1600-214 Lisboa

Portugal anajop@netcabo.pt 